\title{
PROMOSI GIZI MELALUI METODE EMO DEMO UNTUK MENGUBAH PERSEPSI IBU TENTANG MAKANAN JAJANAN BERBASIS PANGAN LOKAL
}

\author{
Lilik Hidayanti ${ }^{1}$, Sri Maywati ${ }^{2}$ \\ ${ }^{1,2}$ Fakultas Ilmu Kesehatan, Universitas Siliwangi, Tasikmalaya \\ *E-mail: Lilikhidayanti@unsil.ac.id
}

\begin{abstract}
High consumption of food snacks can cause decreased of food intake of children aged 0-5 years. Food snacks contain much of sucrose and salt but a little protein so eventually decreasing their nutritional status. To solve this problem, mothers can make food snack by themselves from local foods. Promoting local food is very important to introduce and to increase of understanding of mother about composition and nutritional contain of local food. The aim of this activity was changing mother perception about used of local foods (breadfruit and Tilapia fish) as raw materials of food snack for children aged 0-5 years. This activity used Emo Demo method with theme "cheap food snack, Rich of nutrition". Subjects were 30 mothers who had child aged 0-5 years and also always came to Posyandu in Sukarame, Tasikmalaya. This activities including three stages, that were planning, implementation, and evaluation. Based on this activity, the suggestion was to continue this activity with training so the subjects were able to make foods snack using local foods (Breadfruit and Tilapia fish) as raw materials.
\end{abstract}

Keywords: Children aged 0-5 years; Food snack; Local food

\section{PENDAHULUAN}

Gizi kurang yang salah satu diantaranya adalah stunting banyak diderita oleh anakanak dan masih menjadi masalah kesehatan masyarakat di Negara-negara berkembang, walaupun prevalensinya mulai cenderung menurun seiring dengan terjadinya perbaikan ekonomi (Khan et al., 2016). Pada tahun 2017, jumlah balita yang menderita stunting di seluruh dunia sebanyak 22,2\% (World Bank, 2017).
Dampak stunting adalah rendahnya perkembangan dan kemampuan kognitif pada anak(Duc, 2009; Civelek etal., 2014; Children et al., 2018). Di samping itu, gizi kurang juga berkontribusi terhadap $45 \%$ penyebab kematian pada anak dan berkontribusi sebesar $11 \%$ terhadap beban masalah kesehatan anak di seluruh dunia (Mcglynn Mph et al., 2018). Pada saat dewasa, anak-anak yang menderita stunting berisiko lebih besar terkena penyakit degeneratif seperti PJK (Deboer et al., 2013; 
Hossain et al., 2017; Rolfe et al., 2018) dan hipertensi (Clemente et al., 2012; S Rao, 2016).

Masalah stunting ini juga akan memberikan dampak pada perekonomian (Norris et al., 2014; Hoddinott, Behrman, et al., 2018). Oleh karena itu, masalah stunting dapat berpengaruh pada daya saing bangsa (Nation Competitiveness) di masa-masa yang akan datang (BAPPENAS, 2012). Asupan makan merupakan faktor penyebab langsung terjadinya masalah gizi kurang pada balita. Asupan makan merupakan faktor penyebab langsung terjadinya masalah gizi kurang pada balita.

Kebiasaan makan anak dibentuk sejak tahun pertama kehidupannya sehingga masa kanak-kanak dianggap sebagai fase kritis untuk membentuk pola makan yang sehat (Nicklaus and Remy, 2013; Loth et al., 2014; Nicklaus, 2017). Pola makan ini akan terus berlanjut hingga anak tumbuh menjadi dewasa (De Cosmi, Scaglioni and Agostoni, 2017). Anak sangat mengemari makanan jajanan karena memiliki rasa manis, dan gurih, memiliki warna yang terang dan memiliki tekstur yang lembut (Liem and Zandstra, 2009; Saldivar, 2015).

Makanan jajanan mengandung gula dan garam yang tinggi, namun rendah protein dan seringkali mengandung zat aditif (BTM) serta tidak terjamin kemanannya (Martyn et al., 2013; Al-Harthy et al., 2016). Makanan jajanan adalah makanan dan minuman yang dipersiapkan dan/atau dijual oleh pedagang di tempat tertentu, misalnya di rumah, kios ataupun di keramaian-keramaian umum (Hess, Jonnalagadda and Slavin, 2016).

Makanan jajanan biasanya dapat langsung dimakan atau dikonsumsi tanpa pengolahan atau persiapan lebih lanjut. Namun belum banyak yang menyadari bahwa makanan jajanan yang disiapkan secara tidak baik sangat berisiko terhadap cemaran biologis, fisik, maupun kimia sehingga mutu produk terkait dengan keamanan pangan (Food Safety) menjadi rendah (Rane, 2011). Makanan jajanan seperti itu berpotensi mengakibatkan adanya gangguan kesehatan apalagi pada balita dengan kondisi sistem kekebalan tubuh yang belum sebagus orang dewasa (Okojie and Isah, 2014).

Tingginya konsumsi makanan jajanan dapat menyebabkan penurunan asupan makan pada balita. Hal ini karena anak sudah kenyang mengkonsumsi makanan jajanan sehingga tidak mau makan. Dampak dari perilaku tersebut adalah penurunan tingkat kecukupan energi dan protein yang akhirnya menurunkan status gizi. 
GEMASSIKA: Jurnal Pengabdian Kepada Masyarakat

Vol. 4 No. 1 Mei 2020

Pada dasar apabila ibu memiliki MASALAH, TARGET DAN LUARAN pengetahuan dan keterampilan maka makanan jajanan untuk anak dapat dibuat sendiri dengan memanfaatkan bahan pangan yang diperoleh dari sekitar rumah mereka (bahan pangan lokal) (Wang et al., 2017). Bahan pangan lokal seperti sukun dan ikan mujair dapat dikombinasikan dan diolah menjadi makanan jajanan yang murah dan kaya gizi. Namun seringkali pangan lokal dianggap pangan inferior yang tidak bernilai gizi.

Upaya untuk mengubah pengetahuan dan persepsi seseorang selama ini banyak dilakukan melalui penyuluhan dengan metode ceramah sehingga belum mampu menyentuh rasa atau emosi seseorang. Padahal, untuk merubah persepsi seseorang dibutuhkan kegiatan yang mampu menyentuh emosi seseorang. Emo demo merupakan salah satu metode dalam pendidikan kesehatan dengan menggunakan teknik yang imajinatif dan provokatif sehingga mampu mempengaruhi emosi masyarakat (Amareta and Ardianto, 2017). Kegiatan ini bertujuan untuk mengubah pengetahuan dan persepsi ibu tentang makanan jajanan yang berbasis pangan lokal dengan kandungan gizi yang tinggi melalui metode emo demo.

Kecamatan Sukarameberada diKabupaten Tasikmalaya yang sudah dikenal sejak lama merupakan sentra produksi perikanan darat di Jawa Barat, salah satunya adalah ikan mujair (Oreochromis mossambicus). Produksi ikan mujair di Kabupaten Tasikmalaya sangat besar yaitu 8.509,46 ton/tahun pada tahun 2013, jauh di atas produksi ikan gurame (808,8 ton/tahun), dan ikan mas (6.214, ton/tahun). Ikan mujair merupakan sumber protein hewani yang murah, budidayanya mudah, pertumbuhannya cepat, memiliki daging yang tebal dan ukuran yang besar.

Di kecamatan sukarame juga banyak terdapat tanaman sukun (Artocarpus altilis) yang kaya karbohidrat dan rendah lemak. Tasikmalaya juga merupakan salah satu sentra produksi komoditas sukun di Jawa Barat dan produk ini merupakan unggulan daerah Jawa Barat (Dinas pertanian dan tanaman pangan, Jabar, 2016).

Namun sangat disayangkan, kedua bahan pangan lokal tersebut belum maksimal dimanfaatkan oleh masyarakat di Sukarame. Ikan mujair lebih banyak dijual, sedangkan sukun lebih sering hanya direbus, dijual namun dengan nilai jual yang rendah, sehingga 
pada akhirnya dibiarkan saja membusuk. Padahal kedua pangan lokal tersebut dapat dikombinasikan menjadi makanan jajanan yang bernilai gizi, harganya murah, dan mudah diperoleh.

Data status gizi balita dengan indeks BB/TB skor Z di Puskesmas Sukarame pada tahun 2016 menunjukkan bahwa masih ada 135 Balita yang masuk kategori kurus dan 38 Balita masuk kategori sangat kurus. Ditambah lagi, hasil Penelitian yang yang sudah kami lakukan di Kecamatan Sukarame menunjukkan bahwa masih ada 25,6\% balita yang memiliki Tingkat Kecukupan Energi (TKE) dengan kategori defisit, dan 18,6\% balita memiliki Tingkat Kecukupan Protein (TKP) dengan kategori defisit (Hidayanti and Maywati., 2014).

Target dari kegiatan ini adalah mitra tahu bahwa pangan lokal (ikan mujair dan sukun) memiliki nilai gizi yang tinggi sehingga terjadi perubahan persepsi mitra yang beranggapan bahwa pangan lokal dianggap sebagai pangan inferior. Luaran dari kegiatan ini adalah buku panduan pelaksanaan emo demo camilan sehat kaya gizi berbahan pangan lokal.

\section{METODE PELAKSANAAN}

Sasaran dalam kegiatan ini adalah 30 ibu rumah tangga yang memiliki anak yang berumur di bawah dua tahun (baduta) dan aktif ke Posyandu Edelweid dan Dahlia, Desa Sukarame, Kecamatan Sukarame, Kabupaten Tasikmalaya. Metode promosi kesehatan yang digunakan adalah metode emo demo. Pada kegiatan langkah-langkah yang dilakukan meliputi :

1. Tahap pertama: kegiatan pada tahap pertama adalah pengkajian dan perencanaan kegiatan. Metode yang dilakukan dalam kegiatan ini adalah tim PPM UNSIL memberikan fasilitasi kepada koordinator kader, tokoh masyarakat (RT), dan perwakilan masyarakat melakukan diskusi dan curah pendapat untuk membuat pengkajian dan perencanaan pelaksanaan program pengabdian kepada masyarakat

2. Tahap kedua: kegiatan pada tahap kedua adalah pelaksanaan pengabdian masyarakat dengan metode yang dilakukan adalah Emo-Demo "Camilan murah kaya gizi”. Kegiatan emo demo terdiri dari 2 kegiatan yaitu 1) kegiatan Emo-Demo makanan jajanan yang tidak sehat dan 2) kegiatan emo demo makanan jajanan sehat "Camilan Murah Kaya Gizi”. Alat bantu yang digunakan dalam kegiatan ini adalah slide, contoh makanan jajanan sehat, dan contoh makanan 
jajanan tidak sehat digunakan. Alat bantu tersebut digunakan dengan pertimbangan agar sasaran di samping dapat melihat gambar-gambar yang menarik dan dari slide juga dapat melihat secara nyata makanan jajanan sehat dan tidak sehat.

3. Tahap ketiga : kegiatan pada tahap ketiga adalah upaya mengevaluasi bahwa mitra tahu dan telah terjadi perubahan persepsi bahwa pangan lokal aman dikonsumsi oleh balita dan mengandung nilai gizi yang tinggi dilakukan dengan membandingkan pengetahuan mitra sebelum dan sesudah menerima kegiatan promosi dengan metode emo demo melalui pre test dan post test. Untuk mengetahui perbedaan hasil pre test dan post test digunakan analisis pair sample $t$ test. Instrument yang digunakan adalah kuesioner yang berisi kasus untuk mengukur persepsi ibu. Kuesioner diberikan sebelum (pre test) dan setelah kegiatan (post test) dengan mengubah struktur penomoran soal. Analisis univariat digunakan untuk menggambarkan hasil dari skor pre test dan post test. Analisis statistik menggunakan uji Wilcoxon.

\section{HASIL DAN PEMBAHASAN}

Kegiatan ini dilakukan kepada sasaran yaitu kelompok ibu yang memiliki balita dan aktif datang ke Posyandu.

\section{Karakteristik Sasaran}

Tabel 1 menunjukkan bahwa sebagian besar sasaran dalam kegiatan pengabdian kepada masyarat untuk kegiatan ini berpendidikan rendah yaitu sekolah dasar (SD), sedangkan sasaran yang berpendidikan menengah (SMP dan SMA) masing-masing hanya $13,3 \%$. Sasaran yang bekerja hanya satu (1) orang yang bekerja sebagai pedagang, sedangkan sebagian besar sasaran $(96,7 \%)$ tidak bekerja (ibu rumah tangga).

Tabel 1.

Distribusi Frekuensi Karakteristik sasaran

\begin{tabular}{|c|c|c|c|}
\hline No & Variabel & $\mathrm{n}$ & $\%$ \\
\hline \multicolumn{4}{|c|}{ Pendidikan } \\
\hline 1 & SD & 22 & 73,4 \\
\hline 2 & SMP & 4 & 13,3 \\
\hline 3 & SMA & 4 & 13,3 \\
\hline \multicolumn{4}{|c|}{ Pekerjaan } \\
\hline 1 & Bekerja & 29 & 96,7 \\
\hline 2 & $\begin{array}{l}\text { Tidak } \\
\text { Bekerja }\end{array}$ & 1 & 3,3 \\
\hline
\end{tabular}

Menurut (Notoatmodjo, 2012), pengetahuan seseorang dapat dipengaruhi oleh berbagai macam faktor, salah satunya adalah pendidikan. Pendidikan seseorang secara langsung berpengaruh terhadap pengetahuan seseorang, walaupun tidak terkait dengan bidang pengetahuannya. Dengan semakin tingginya pendidikan seseorang maka orang tersebut akan memiliki akses yang lebih luas pada informasi melalui berbagai macam 
media (cetak dan elektronik) sehingga dapat meningkatkan pengetahuannya. Tingkat pendidikan seseorang dapat memberikan pengaruh terhadap pengetahuan seseorang dan pada akhirnya akan berkaitan dengan sikap dan prakteknya.

Pada kegiatan ini dilakukan pemberian pesan yang berusaha mengugah emosi sasaran sehingga akan terjadi perubahan persepsinya. Pesan disampaikan melalui contoh-contoh nyata seperti menunjukkan makanan jajanan yang sehat berbahan pangan lokal dan makanan jajanan yang tidak sehat kepada sasaran. Sehingga walaupun sasaran berpendidikan rendah, namun diharapkan dengan menampilkan contoh secara nyata akan membantu lebih cepat memahami dan mengugah emosi sehingga terjadi perubahan persepsi.

Sasaran dalam kegiatan ini, sebagian besar ibu yang tidak bekerja dan menghabiskan sebagian besar waktunya di rumah sebagai ibu rumah tangga. Hal ini menyebabkan ibu kurang berinteraksi dengan orang lain untuk mendapatkan informasi baru, atau pergi keluar sehingga mendapatkan informasi baru. Informasi bisa diperoleh dari manapun saat seseorang melakukan pergerakan ke luar rumah. Seperti misalnya, spanduk-spanduk yang terpampang di jalan, baliho, ataupun dari perbincangan dengan orang lain yang memiliki pengetahuan lebih. Ibu yang tidak bekerjalebih bersifat pasifdalam mendapatkan informasi seperti melalui tontonan di televisi (Freisling, Haas and Elmadfa, 2010).

\section{Karakteristik Suami}

Tabel 2.

Distribusi Frekuensi Karakteristik Suami

\begin{tabular}{lcrc}
\hline No & Variabel & $\mathrm{n}$ & $\%$ \\
\hline Pendidikan & & & \\
1 & SD & 22 & 73,3 \\
2 & SMP & 4 & 13,3 \\
3 & SMA & 4 & 13,3 \\
\hline \multicolumn{3}{l}{ Pekerjaan } \\
1 & Tidak Bekerja & 0 & 0 \\
2 & Buruh & 23 & 76.7 \\
3 & Pedagang & 4 & 13.3 \\
4 & Wiraswasta & 3 & 10.0 \\
\hline
\end{tabular}

Tabel 2 menunjukkan bahwa, dari 30 sasaran sebagian besar memiliki suami yang berpendidikan SD (73,3 \%), dan sisanya 8 orang berpendidikan menengah yaitu (SMP dan SMA). Pendidikan suami dapat memberikan pengaruh pada semakin terbuka pemikiran suami terkait dengan dukungan terhadap pola pengasuhan anak. Sementara itu, suami dengan pendidikan rendah memiliki keterbatasan juga dalam melakukan transfer knowledge dan dukungan dari sisi peningkatan pengetahuan kepada istrinya.

Suami sasaran sebagian besar bekerja sebagai buruh dengan pendapatan yang 
tidak tentu setiap bulan. Hal ini diduga akan memberikan dampak pada pemilihan makanan jajanan yang mampu dibeli oleh sasaran. Makanan jajanan yang mampu dibeli berkisar maksimal seharga Rp 1000,- saja sehingga jenis makanan jajanan yang dibeli juga memiliki kualitas kemanan dan gizi yang masih kurang.

\section{Karakteristik Anak}

Tabel 3.

Distribusi Frekuensi Karakteristik Anak Sasaran

\begin{tabular}{|c|c|c|c|c|c|}
\hline No & Variabel & & & $\mathbf{n}$ & $\%$ \\
\hline \multicolumn{6}{|c|}{ Jenis Kelamin } \\
\hline 1 & Laki-lak & & & 13 & 43.3 \\
\hline 2 & Peremp & & & 17 & 56.7 \\
\hline \multicolumn{2}{|c|}{ Variabel } & Mean & $\mathrm{SD}$ & Min & Maks \\
\hline 1 & $\begin{array}{l}\text { Jumlah } \\
\text { Anak }\end{array}$ & 2 & 1,2 & 1 & 5 \\
\hline 2 & $\begin{array}{l}\text { Umur } \\
\text { Anak }\end{array}$ & 33,8 & 16,8 & 6 & 60 \\
\hline
\end{tabular}

Sasaran yang memiliki anak perempuan $(56,7 \%)$ jumlahnya hampir sama dengan yang memiliki anak laki-laki (43,3\%). Rata-rata jumlah anak dalam keluarga sasaran adalah 2 dengan kisaran antara 1-5 orang per keluarga.

\section{Tahapan Pelaksanaan Promosi Gizi melalui Emo Demo}

Kegiatan Emo Demo dilakukan dengan mengumpulkan sasaran di rumah salah satu sasaran selama 5 jam mulai dari jam 9 pagi sampai dengan jam 3 sore dengan jeda selama 1 jam untuk sholat dhuzur dan makan. Secara umum kegiatan emo demo ini dilaksanakan dalam 2 (dua) tahap sesuai dengan panduan berikut :

1. Emo demo makanan jajanan tidak sehat

a. Tujuan: untuk menunjukkan bahwa makanan jajanan yang tidak sehat sangat menjijikan walaupun memiliki rasa yang enak dan anakanak menyukainya, namun makanan jajanan ini mengandung BTM, pewarna dan minyak yang telah dipakai berulang kali sehingga tidak sehat dan dapat membahayakan kesehatan anak

b. Pesan yang akan disampaikan : makanan jajanan tidak sehat itu menjijikkan

c. Alat dan bahan yang dibutuhkan : contoh makanan jajanan tidak sehat yang termasuk dalam kelompok frozen food seperti sosis, nugget, rolade, otak-otak, cilok dengan warna oranye yang terang

d. Aktivitas emo demo

1) Fasilitor menampilkan makanan jajanan yang telah disiapkan 
dan menanyakan apakah sasaran pernah memberikan makanan jajanan tersebut kepada anak mereka? Atau sasaran pernah melihat ibu lain memberikan makanan jajanan tersebut kepada anaknya?. Pertanyaan diberikan kepada 3 orang sasaran secara acak. Hasil jawaban sasaran seluruhnya menyatakan pernah memberikan dan pernah melihat tetangga mereka memberikan makanan jajanan tersebut kepada anak merekan

2) Fasilitator memaparkan dengan menunjukkan :

a) Cara penyimpanan makanan jajanan frozen food yang dilakukan oleh penjual di pasar saat fasilitator membeli makanan jajanan tersebut yaitu diletakkan saja dalam wadah dan terpapar matahari secara langsung tanpa disimpan di lemari pendingin

b) Frozen food berbahan dasar ayam, ikan yang termasuk kelompok perishable food namun ternyata bisa awet tidak mengalami kerusakan setelah disimpan selama 3 hari di suhu kamar.

c) Makanan jajanan tersebut berwarna oranye terang dan keras

d) Makanan jajanan yang berbahan baku makanan hewani seperti ayam, ikan, dan daging yang secara umum harganya mahal namun saat berbentuk makanan jajanan dijual dengan harga yang murah. Disampaikan oleh fasilitator harga per bungkus yang berisi 10 biji berkisar antara 2 ribu sampai 5 ribu rupiah.

\section{e. Chit chat:}

1) Apakah ada yang mau makan makanan jajanan tersebut?

Fasilitator menanyakan kepada sasaran apakah masih mau memberikan makanan jajanan tidak sehat yang mengandung BTM kepada anak mereka dan seluruh sasaran menyatakan tidak mau memberikannya. 
2) Menurut ibu apakah makanan jajanan ini cocok diberikan pada anak-anak?

Fasilitator menanyakan apakah makanan jajanan yang tidak sehat ini cocok diberikan kepada anak mereka yang masih kecil yang masih rentan terhadap penyakit, dan seluruh sasaran menyatakan tidak mau

3) Setelah ibu melihat betapa menjijikkan makanan jajanan ini, apakah ibu masih mau memberikannya untuk anak ibu?

f. Apakah perbedaannya makanan jajanan tersebut dengan makanan jajanan yang sehat?

Fasilitator menampilkan contoh makanan jajanan yang sehat dan tidak sehat serta meminta setiap sasaran melihat kemudian menyebutkan perbedaannya.

g. Fasilitator mengugah emosi sasaran dengan menampilkan dampak penggunaan BTM pada makanan jajanan kepada sasaran.

Melalui slide, fasilitator menampilkan dampak konsumsi makanan jajanan tidak sehat kepada sasaran

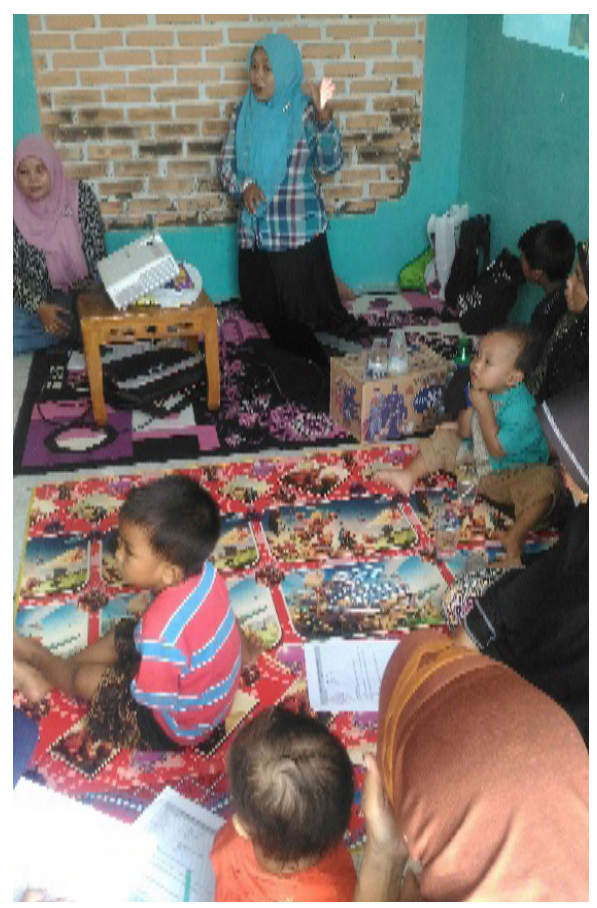

Gambar 1.

Pemaparan dampak makanan jajanan tidak sehat

2. Emo demo makanan jajanan sehat “Camilan Murah Kaya Gizi)

a. Tujuan : menunjukkan bahwa makanan jajanan yang sehat dan bergizi dapat dibuat dengan harga yang murah dan bahan dapat diperoleh dari sekitar mereka

b. Pesan yang disampaikan : makanan jajanan sehat dan bergizi dapat dibuat sendiri, dari bahan yang ada di sekitar kita dengan harga yang murah

c. Pesan yang disampaikan : tertantang mencoba membuat sendiri makanan jajanan sehat 
d. Alat dan bahan yang digunakan : kertas dan alat tulis, slide dengan gambar potensi pangan di daerah Sukarame

e. Aktivitas emo demo:

1) Fasilitator meminta sasaran menuliskan potensi pangan hasil kebun, sawah, ladang dan balong yang ada di sekitar rumah mereka. Kemudian menampilkan jawaban dalam slide.

Rata-rata potensi pangan lokal yang disebutkan oleh sasaran adalah ikan, sukun, singkong dan ubi.

2) Fasilitator membantu melakukan analisis kandungan gizi dari pangan yang disebutkan, dan juga memberikan beberapa alternative makanan jajanan yang dapat dibuat dari pangan tersebut.

Fasilitator menyampaikan bahwa kandungan gizi dalam pangan lokal tersebut adalah karbohidrat dan protein. Fasilitator juga menyampaikan bahwa pangan lokal tersebut dapat dibuat menjadi makanan jajanan yang sehat untuk anak seperti pukis sukun, takoyaki mujair, bolabola sukun isi ikan, dll

3) Fasilitator menawarkan perubahan konsumsi makanan jajanan yang sehat dan bergizi dengan menampilkan buah suku dan ikan mujair sebagai bahan baku pembuatan makanan jajanan

Fasilitator menanyakan kepada sasaran apakah mau mencoba membuat makanan jajanan sehat untuk anaknya dan seluruh sasaran bersedia mencobanya.

4) Fasilitator melakukan demo pembuatan makanan jajanan sehat berbahan baku pangan lokal, selanjutnya menawarkan kepada sasaran untuk mencoba membuat makanan jajanan seperti yang sudah dicontohkan oleh fasilitator. Satu kelompok sasaran yang terdiri dari 3 orang maju kedepan dan mencoba membuat makanan jajanan sehat berbahan baku pangan lokal. 


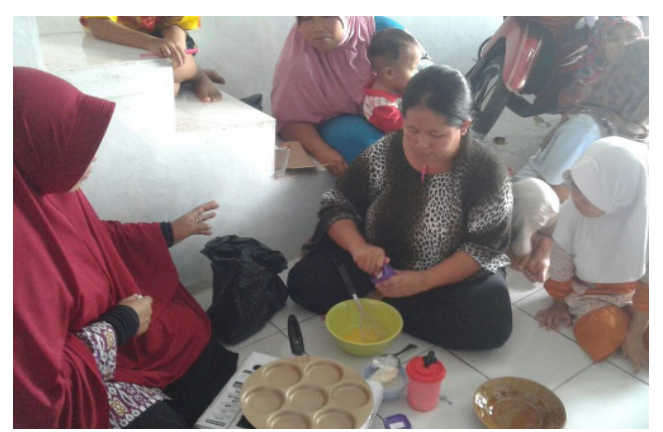

Gambar 2.

Sasaran mencoba membuat makanan jajanan sehat berbahan baku pangan lokal

5) Fasilitator membagikan makanan jajanan berbahan baku buah sukun dan ikan mujair berupa pukis, takoyaki, kue lumpur dan donat sukun, kemudian menanyakan tanggapan terhadap 5 orang sasaran.
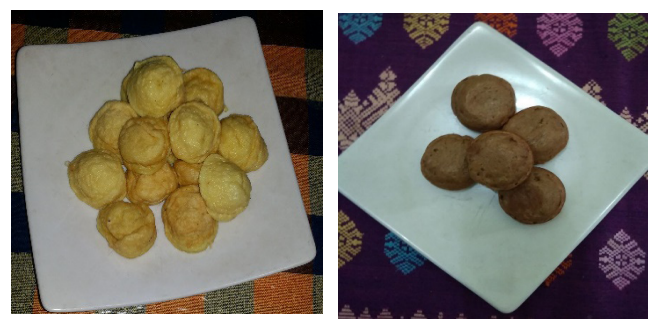

\section{Gambar 3.}

Contoh makanan jajanan yang dibuat oleh sasaran

Kelima sasaran yang diminta mencoba menyatakan makanan jajanan yang dibuat memiliki rasa yang enak. Selanjutnya setiap sasaran dipersilahkan untuk mencoba makanan jajanan yang telah dibuat.

6) Fasilitator menyampaikan kandungan gizi makanan jajanan yang terbut dari buah sukun dan ikan mujair.

Fasilitator menyampaikan bahwa kombi-nasi sukun dan ikan mujair mengandung energi dan protein yang dapat mendukung pertumbuhan anak mereka

Untuk mengetahui perbedaan persepsi sasaran terhadap makanan jajanan yang diberikan kepada anaknya diketahui dengan cara memberikan kuesioner yang berupa cerita atau kasus yang biasa dialami oleh sasaran sebelum dan sesudah kegiatan dilakukan.

Tabel 4.

Penghitungan Statistik Skor Pre Test dan Post Test

\begin{tabular}{lcccc}
\hline \multicolumn{1}{c}{ Skor } & Mean & SD & Min & Maks \\
\hline $\begin{array}{l}\text { Sebelum } \\
\text { Emo Demo }\end{array}$ & 9,2 & 1,9 & 6 & 12 \\
$\begin{array}{l}\text { Setelah Emo } \\
\text { Demo }\end{array}$ & 12,9 & 2,0 & 8 & 15 \\
\hline
\end{tabular}

Kuesioner pre test diberikan sebelum kegiatan emo demo dilakukan, sedangkan kuesioner post test diberikan setelah kegiatan emo demo dilakukan. Kuesioner berisi 10 
buah kasus pemberian makanan jajanan kepada anak khususnya balita, kemudian pertanyaan berupa tanggapan atau persepsi ibu terkait kasus yang diberikan. Hasil pre test menunjukkan bahwa sebelum kegiatan emo demo hampir separuh (36,7 \%) sasaran menyatakan bahwa makanan jajanan boleh diberikan kepada anak sejak kecil. Sedangkan pada post test hanya 1 orang $(3,3 \%)$ sasaran yang mengijinkan pemberian makanan jajanan kepada anaknya. Sebelum kegiatan ada 20 sasaran yang menyatakan anak tidak boleh dibelikan cilok yang diberi saos atau bumbu instant. Jumlah ini meningkat menjadi 25 sasaran setelah kegiatan dilaksanakan. Jumlah sasaran yang setuju bahwa mie instant tidak boleh terlalu sering diberikan kepada anak juga meningkat dari 19 sasaran sebelum kegiatan menjadi 21 sasaran sesudah kegiatan.

Hasil penghitungan nilai statistik pre test dan post test menunjukkan adanya perbedaan rerata skor hasil tanggapan atau persepsi sasaran yang diberikan dengan cara menjawab soal kasus dalam kuesioner. Ada peningkatan rerata post test menjadi 12,9 dari rerata pre test sebesar 9,2. Kisaran skor juga mengalami perubahan pada saat pre test dan post test.

Peningkatan rerata ini menunjukkan bahwa persepsi ibu meningkat ke arah positif artinya ibu semakin berpersepsi ke arah yang lebih baik dalam pemberian makanan jajanan kepada anaknya. Ibu mulai memahami bahwa makanan jajanan yang tidak sehat dapat mengandung BTM dan dapat berdampak buruk pada kesehatan anak pada saat ini maupun pada masa yang akan datang. Ibu juga mulai berubah persepsinya terhadap penggunaan pangan lokal sebagai bahan pembuatan makanan jajanan untuk anak mereka. Mereka mulai sadar bahwa pangan lokal apabila dikombinasikan dengan baik dapat memberikan kontribusi terhadap kebutuhan gizi anak.

Emotional Demonstration atau lebih dikenal dengan istilah emo demo adalah suatu kegiatan aktif berbasis pada perubahan perilaku (pengetahuan, sikap dan praktek) pada kelompok masyarakat target. Emo Demo merupakan strategi komunikasi perubahan perilaku yang menggunakan penggabungan Social and Behavior Communication Change (SBCC) yaitu proses interaktif antara individu, kelompok atau masyarakat dalam mengembangkan strategi komunikasi untuk mencapai perubahan perilaku secara positif (SNV et al., 2017).

Behaviour Communication Definition (BCD) yaitu proses komunikasi yang memanfaatkan secara langsung konstruksi psikologis individu dengan melibatkan 
perasaan, kebutuhan dan pemikiran. Behavior change communication (BCC) dapat meningkatkan pengetahuan, praktek dan dampak kesehatan pada bayi dan anak-anak (Hoddinott, Ahmed, et al., 2018). Oleh karena itu BCC dapat menjadi kunci utama untuk menyelesaikan masalah kesehatan, dengan cara menginspirasi dan memberdayakan masyarakat agar mereka dapat membuat pilihan-pilihan bagi dirinya sendiri dan keluarganya agar dapat hidup dengan sehat, seperti memberikanan makanan jajanan yang sehat kepada anak.

Hasil uji statistik dengan menggunakan uji wilcoxon menunjukkan ada perbedaan skor jawaban sasaran sebelum dan sesudah kegiatan emo demo dilakukan. Hal ini menunjukkan bahwa ada perubahan persepsi sasaran yaitu ibu dalam pemberian makanan jajanan kepada anaknya.

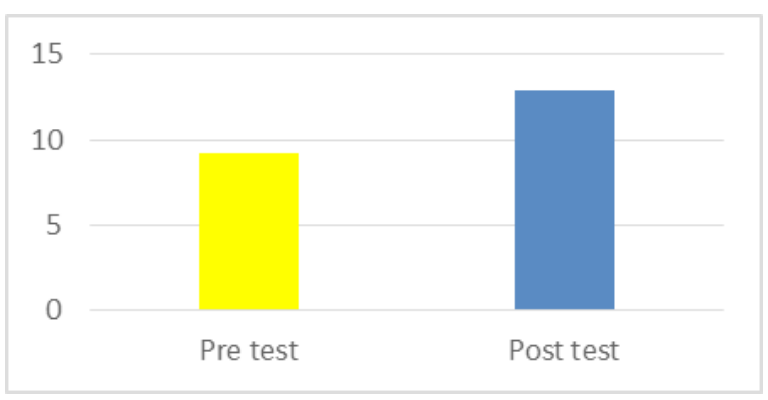

pValue : 0,001

\section{Grafik 1.}

Perbedaan Skor Pre Test dan Post Test

Pola makan yang sehat mulai saat anakanak sampai dewasa sangat penting untuk pertumbuhan fisik dan dan perkembangan otak. Pola makan berubah selama tahun-tahun pertama kehidupan, pada saat anak mulai bisa bertanya apa, kapan, dan jumlah makanan yang akan dikonsumsinya (Jacka et al., 2011). Anak-anak belajar mengenal makanan dari pengalaman langsung mencoba makanan yang diberikan kepadanya atau melihat makanan yang dikonsumsi oleh orang lain. Anak-anak mau mengkonsumsi makanan tergantung pada apa yang telah dikenalnya (Paroche et al., 2017).

Banyak penelitian yang menyatakan bahwa orang tua mempunyai pengaruh yang besar terhadap pembentukan pola makan anak. Sikap anak terhadap makanan dan kesukaannya terhadap makanan sangat dipengaruhi oleh keluarganya terutama ibunya (Peters et al., 2014) .

Oleh karena itu, kegiatan emo demo ini dilakukan kepada ibu yang memiliki anak balita sehingga sejak dini ibu sudah menyadari bahwa pola makan yang sehat harus ditanamkan kepada anak sejak dini. Dengan berubahnya persepsi ibu terhadap makanan jajanan maka anak juga bisa mengenal makanan jajanan yang sehat sejak dini sehingga saat dewasa sudah terbiasa hanya mangkonsumsi makanan jajanan yang sehat. 


\section{KESIMPULAN DAN SARAN}

Kesimpulan dalam kegiatan promosi gizi dengan menggunakan metode emo demo menunjukkan adanya perubahan persepsi sasaran yaitu ibu ke arah yang lebih baik berdasarkan peningkatan skor sebelum kegiatan dilakukan dan sesudahnya. Perubahan persepsi tersebut harus diikuti dengan adanya keterampilan sehingga ibu mampu melakukan praktek pembuatan makanan jajanan berbahan ikan mujair dan buah sukun. Oleh karena itu, rekomendasi dari kegiatan ini adalah melanjutkan dengan memberikan pelatihan pembuatan makanan jajanan berbahan ikan mujair dan buah sukun.

\section{UCAPAN TERIMA KASIH}

Ucapan terima kasih disampaikan kepada Direktorat Riset dan Pengabdian Masyarakat (DRPM) Kementrian Ristek dan Pendidikan Tinggi (Kemenristek Dikti) yang telah memberikan bantuan pendanaan melalui Hibah PKM sehingga kegiatan ini dapat dilaksanakan.

\section{DAFTAR PUSTAKA}

BAPPENAS, (2012). Tujuan Pembangunan Milenium Republik Indonesia. doi: 10.1007/ s00787-008-0688-6.

Al-Harthy, A. et al. (2016) 'Food Additives Content in Selected Snack Foods and Beverages and Public Perception of E-Numbers in Muscat, Oman', Athens Journal of Health, 4(1), pp. 83-96. doi: 10.30958/ajh.4-1-5.

Amareta, D. I. and Ardianto, E. T. (2017) 'Penyuluhan Kesehatan dengan Metode Emo Demo Efektif Meningkatkan Praktik CTPS di MI Al-Badri Kalisat Kabupaten Jember', pp. 246250.

Bank, W. (2017) 'Prevalence of stunting, height for age (\% of children under 5)'.

Children, G. et al. (2018) 'Early Childhood Stunting Is Associated with Lower Developmental Levels in the Subsequent', (August), pp. 823-828. doi: 10.3945/jn.114.200261.Downloaded.

Civelek, M. et al. (2014) 'HHS Public Access', 15(1), pp. 34-48. doi: 10.1038/nrg3575.Systems. 
GEMASSIKA: Jurnal Pengabdian Kepada Masyarakat

Vol. 4 No. 1 Mei 2020

Clemente, A. P. et al. (2012) 'Mild stunting is associated with higher blood pressure in overweight adolescents', Arq Bras Cardiol, 98(1), pp. 6-12. doi: 10.1016/j.canep.2009.10.004.

De Cosmi, V., Scaglioni, S. and Agostoni, C. (2017) 'Early taste experiences and later food choices', Nutrients, 9(2), pp. 1-9. doi: 10.3390/nu9020107.

Deboer, M. D. et al. (2013) 'NIH Public Access', 70(11), pp. 642-653. doi: 10.1111/j.17534887.2012.00543.x.Early.

Duc, L. T. (2009) 'The effect of early age stunting on cognitive achievement among children in Vietnam', (45), p. 20. doi: 978-1904427-50-6.

Freisling, H., Haas, K. and Elmadfa, I. (2010) 'Mass media nutrition information sources and associations with fruit and vegetable consumption among adolescents', Public Health Nutrition. University of Basel Library, 13(2), pp. 269-275. doi: 10.1017/ S1368980009991297.

Hess, J. M., Jonnalagadda, S. S. and Slavin, J. L. (2016) 'What Is a Snack, Why Do We Snack, and How Can We Choose Better Snacks? A Review of the Definitions of Snacking, Motivations to Snack, Contributions to Dietary Intake, and Recommendations for Improvement', American Society for Nutrition. Adv Nutr, 11(2), pp. 161-178. doi: 10.3945/an.115.009571.466.

Hidayanti, L. and Maywati., S. (2014) 'Ketahanan Pangan (Food Security) dan Status Gizi Balita Keluarga Miskin di Kecamatan Sukarame Kabupaten Tasikmalaya. Laporan Penelitian.'

Hoddinott, J., Behrman, J. R., et al. (2018) 'Adult consequences of growth failure in early childhood 1-3', (August), pp. 1170-1178. doi: 10.3945/ajcn.113.064584.1.

Hoddinott, J., Ahmed, A., et al. (2018) 'Nutrition behaviour change communication causes sustained effects on IYCN knowledge in two cluster-randomised trials in Bangladesh', Maternal and Child Nutrition, 14(1), pp. 1-10. doi: 10.1111/mcn.12498.

Hossain, M. et al. (2017) 'Evidence-based approaches to childhood stunting in low and middle income countries: a systematic review', pp. 903-909. doi: 10.1136/ archdischild-2016-311050. 
Jacka, F. N. et al. (2011) 'A prospective study of diet quality and mental health in adolescents', PLoS ONE, 6(9), pp. 1-7. doi: 10.1371/journal.pone.0024805.

Khan, G. N. et al. (2016) 'Prevalence and associated factors of malnutrition among children under-five years in Sindh, Pakistan : a cross-sectional study', BMC Nutrition. BMC Nutrition, pp. 1-8. doi: 10.1186/s40795-016-0112-4.

Liem, D. G. and Zandstra, L. H. (2009) 'Children's liking and wanting of snack products: Influence of shape and flavour', International Journal of Behavioral Nutrition and Physical Activity, 6, pp. 1-10. doi: 10.1186/1479-5868-6-38.

Loth, K. et al. (2014) 'Personal and socio-environmental predictors of dieting and disordered eating behaviors from adolescence to young adulthood: 10-year longitudinal findings', $J$ Adolesc Health, 55(5), pp. 705-712. doi: 10.1016/j.jadohealth.2014.04.016.

Martyn, D. M. et al. (2013) 'Food additives and preschool children', Proceedings of the Nutrition Society, 72(1), pp. 109-116. doi: 10.1017/S0029665112002935.

Mcglynn Mph, P. J. et al. (2018) 'Critical examination of evidence for the nutritional status of children in Papua New Guinea-a systematic review', Asia Pac J Clin Nutr, 27(1), pp. 1-18. doi: 10.6133/apjcn.042017.02.

Nicklaus, S. (2017) 'The Role of Dietary Experience in the Development of Eating Behavior during the First Years of Life', Annals of Nutrition and Metabolism, 70(3), pp. 241-245. doi: $10.1159 / 000465532$.

Nicklaus, S. and Remy, E. (2013) 'Early Origins of Overeating: Tracking Between Early Food Habits and Later Eating Patterns', Current Obesity Reports, 2(2), pp. 179-184. doi: 10.1007/s13679-013-0055-x.

Norris, S. A. et al. (2014) 'Africa in transition: growth trends in children and implications for nutrition', Annals of nutrition \& metabolism, 64, pp. 8-13. doi: 10.1159/000365122.

Notoatmodjo, S. (2012) Promosi Kesehatan dan Perilaku Kesehatan. Jakarta: Rineka Cipta.

Okojie, P. W. and Isah, E. C. (2014) 'Sanitary conditions offood vending sites and food handling practices of street food vendors in Benin city, Nigeria: Implication for food hygiene and safety', Journal of Environmental and Public Health, 2014. doi: 10.1155/2014/701316. 
GEMASSIKA: Jurnal Pengabdian Kepada Masyarakat

Vol. 4 No. 1 Mei 2020

Paroche, M. M. et al. (2017) 'How infants and young children learn about food: A systematic review', Frontiers in Physiology, 8(JUL). doi: 10.3389/fpsyg.2017.01046.

Peters, J. et al. (2014) 'Parental influences on the diets of 2- to 5-year-old children: Systematic review of qualitative research', Journal of Early Childhood Research, 12(1), pp. 3-19. doi: 10.1177/1476718X13492940.

Rane, S. (2011) 'Street Vended Food in Developing World: Hazard Analyses', Indian Journal of Microbiology, 51(1), pp. 100-106. doi: 10.1007/s12088-011-0154-x.

Rolfe, E. D. L. et al. (2018) 'Associations of stunting in early childhood with cardiometabolic risk factors in adulthood', PLoS ONE, 13(4), pp. 1-13. doi: 10.1371/journal.pone.0192196.

S, Rao. (2016) 'Early Postnatal Stunting Increases Risk of Hypertension among Young Rural Adults from India- Pune Rural Cohort', Journal of Nutrition and Health Sciences, 3(1), pp. 1-8. doi: 10.15744/2393-9060.3.101.

Saldivar, S. O. S. (2015) Snack Foods: Types and Composition. 1st edn, Encyclopedia of Food and Health. 1st edn. Elsevier Ltd. doi: 10.1016/B978-0-12-384947-2.00633-4.

SNV et al. (2017) 'Triggering for positive behaviour change in nutrition Insights from Sustainable Nutrition for All in Uganda and Zambia', (2), p. 20. Available at: http://www. snv.org/public/cms/sites/default/files/explore/download/sn4a_technical_paper_no_2_triggering_0.pdf.

World Bank (2017) 'Api_Sh'.doi: 10.1103/RevModPhys.81.591.

Wang, L. et al. (2017) 'Feeding styles, parenting styles and snacking behaviour in children attending primary schools in multiethnic neighbourhoods: A cross-sectional study', BMJ Open, 7(7), pp. 1-10. doi: 10.1136/bmjopen-2016-015495. 